\title{
Mine(s) and Others
}

\section{MARISA MORÁN JAHN}

Artist, Department of Art, Culture, and Technology, Massachusetts Institute of Technology; Assistant Professor, The New School

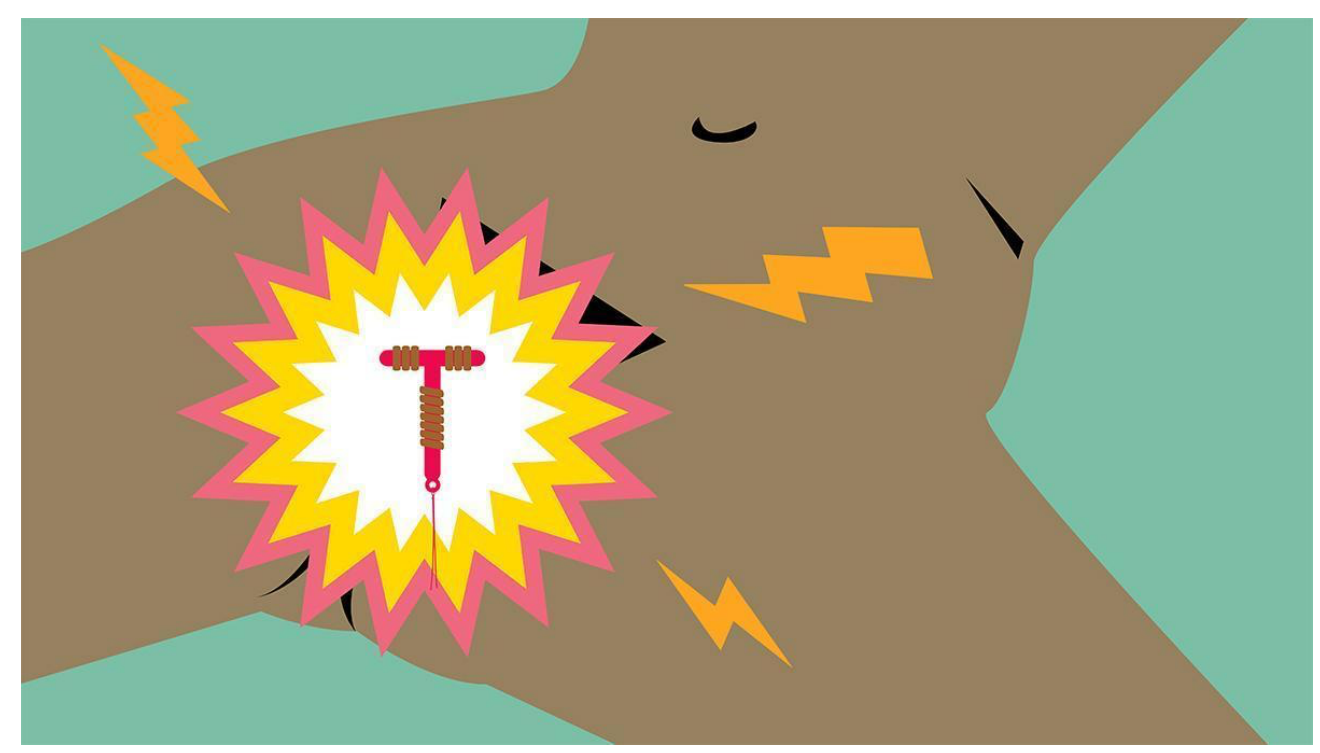

Figure 1. BANG!, 2019. Marisa Morán Jahn, sublimated dye metallic print @ Marisa Morán Jahn. Bang! finds inspiration from Gustave Courbet's L'Origine du Monde (1866), a painting that Glenn Lowry, Chief Curator at the Museum of Modern Art, refers to as "one of the most erotic paintings in Western art history." As a 21st century feminist reboot, Bang! interrupts the male gaze with the IUD, suggesting that the fulfilment of women's libidinal desire is coterminous with reproductive technologies.

\section{INTRODUCTION}

One day, as I was filing some papers, I came across my medical records and found where it had been written: "Birth Control - Copper T Intrauterine Device (IUD)." How could I be so ignorant about this piece of technology that's inside my very own snatch? My self-disappointment then turned to wonder. How does the copper even work? When did they figure this out? And where did the copper in my snatch come from? 
So begins Snatchural History of Copper, a project in which I unearth (pun intended) where "the copper in my snatch" comes from. What unfolds is a cosmological exploration of a mineral that lives with(in) us and on which our households, cities, digital desires, and selves depend.

\section{Mineral Dependencies}

A reddish mineral found in air, water, soil, plants, and animals, copper is a naturally occurring element on which our bodies depend. Copper's most notable properties include its low melting point, malleability, and conductivity. Copper's propensity for readily exchanging ions with elements it encounters lends it antimicrobial properties, leading to a wide range of applications throughout history: from the copper pipes used in ancient Egypt's plumbing, to the copper pitchers still used around the world to purify water, to hospitals' use of doorknobs made of bronze, a copper alloy, to cut down on bacterial infections.

The discovery of bronze pessaries (contraceptive and uterine support devices) dating back to ancient Rome circa 200-400 BCE signals early knowledge of copper's spermicidal effect—or as I would say, copper's ability to zap sperm. ${ }^{1}$ Today, over 150 million women across the world rely upon both copper and hormonal IUDs. ${ }^{2}$ Controversy marks the modern history of the IUD: invented in the 1960s as a tool for women's sexual self-liberation and promoted by birth control advocate Margaret Sanger, the IUD quickly became a tool to enforce a Western, neo-Malthusian agenda of population control. By the 1990s, through institutional complicity of organizations including Planned Parenthood, The Rockefeller Foundation, and governmental entities, millions of women in the Global South and low-income women of color in the United States were forcibly sterilized through the non-consensual insertion of IUDs into their bodies.

Despite its instrumental role in women's subjugation, ethnographer Chikako Takeshita contends that throughout the Global South, the IUD has offered a "politically versatile device in women's struggles to achieve personal reproductive goals."

[The IUD] demonstrates how women have mitigated antinatal government policies, eluded husbands' demands, and bargained with healthcare providers in order to protect their physical health and regulate reproduction in ways that suit them. While the IUD has at times had a negative reputation owing to coercive and non-consented insertions in marginalized women and health problems experienced by its users, [many women] show that the device can also become an ally of a woman's quest for reproductive selfdetermination. The long-acting, provider-controlled, and easily-reversible features of the IUD as well as its inconspicuousness have worked in favor of various women's reproductive strategies. ${ }^{3}$

As Takeshita points out, the IUD's popularity over time lies in its invisibility and long-lasting functionality. Today, these attributes continue to contribute to the device's growing popularity among younger generations in the Global North. In the recent past, the 2016 election of Donald J. Trump to the United States' presidency drove up the sales of IUDs by $900 \%$ : fearing diminished access to reproductive health care, American women turned to a birth control method that could 
outlast a two-term presidency. ${ }^{4}$ The IUD, then, functions as a technological artifact that "diffracts" - to borrow a term from Donna Haraway - a complex geopolitical history. ${ }^{5}$

The copper IUD within my own body invites me to not only recognize my physical, libidinal, social, and ecological interdependencies but to negotiate these relations anew. As an artist whose parents hail from China and Ecuador-two historically significant copper-producing regions in the world-I situate the copper IUD as a device that braids the struggles against the colonization of land (ecocide) and female bodies (or as Loretta J. Ross terms it, "reprocide"). ${ }^{6}$

What follows are excerpts from the performance-lecture I've delivered at Re@ct (2019), Creative Capital (2019), Creative Time (2019), and Arsenal Gallery (2020). I begin the performance on stage wearing everyday street clothes. As I weave these histories on stage, I transform my clothes and personae to become the mythical character, Venus of Aphrodite, addressing my audience as my lover. We are entangled in a passionate but volatile affair that we've got to set straight.

Why Venus of Aphrodite? Western historians claim that copper was first mined between 7,000 and $10,000 \mathrm{BCE}$ on the island of Cyprus; I use 10,000 $\mathrm{BCE}$ as a starting point because this encompasses the period of time when humans were first tinkering with copper. Aside from copper, Cyprus is also the birthplace of Aphrodite, goddess of love. As Aphrodite and copper share the same alchemical symbol $q$, the connection might seem to suggest a relationship of fecundity. But rather than see the female body and land as a passive, fertile site of extraction, I regard fecundity as a source of power to be negotiated.

In the performance, I borrow the psychoanalyst Jacques Lacan's notion of "extimacy" which he uses to refer to the mediation of intimacy through an external object. Lending a contemporary interpretation, sociologist and psychologist Sherry Turkle resituates extimacy to refer to the technological mediation of intimacy. ${ }^{7}$ I build on these precedents, interpreting extimacy to also implicate the material conditions of our technologically mediated intimacies and to focus on copper. For example, in heterosexual entanglements, the copper IUD aids the fulfillment of libidinal desire by mediating fertility. Shifting from analog to digital, today's networked beings rely on copper within motherboards, the copper-lined transatlantic fiber optic cables tethering us to transatlantic exurban server farms, and an array of other copper-based technologies. Through this matrix of copper-reliant technologies, we digitally manage our fertility cycles, stoke romances on dating apps, arrange surrogate parents, etc. In other words, copper is the mineral undergirding extimacy in a digital era.

But including this mineralogical dimension to extimacy then begins to self-reflexively query who mines our copper, what are the socio-ecological externalities, who pays the cost? In fact, the vast majority of copper is "harvested" by women in the Global South, working without proper protection against the industry's toxic byproducts and hazards. These women's overexposure to copper deleteriously impacts their eyes, lungs, nervous systems, as well as their reproductive organs 8 , - a reality revealing the geopolitical asymmetry of our copperscape, in which women of color bear the "body burdens" of an extractive colonialism. ${ }^{9}$ Thus, the paradox of our mineral-libidinal imaginary in the present-day extractive regime rests on the rapacious extraction of copper - that very mineral associated with love and fecundity yet whose geopolitical reality involves the subjugation of bodies 
and land. This aporia between mine(s) and others I explore in the following artwork, seeking resolve.

\section{ZAP!}

Stage directions: The performance begins with a curator reading Marisa's bio and announcing that she will give an artist's talk. Marisa walks on stage towards the podium. She wears a long skirt, a long blouse, "artsy." After greeting the audience and thanking the curator and institution, she opens her laptop to projects slides from her laptop. The following script should be wellpracticed (not to be read), as if Marisa is thinking aloud with slides. Over time, she becomes more and more agitated.

Consider Claus Oldenburg's pop art sculptures featuring larger-than-life, quotidian American household objects - pies, ice cream cones, safety pins, banana peels, clothes pins, mini trowels, baseball bats. Such innocuous objects! A few years ago, I began wondering what it might look like to create a twenty-foot-tall sculpture of the tiny one-inch, T-shaped copper intrauterine device (IUD) used by millions of women across the world yet almost always hidden from view, literally and discursively.

Around the time when Trump assumed the presidency and immediately began imperiling women's reproductive health and denigrating science, I started making sketches of this idea and showing them to friends to get feedback While only a small percentage of male-identifying colleagues recognized the object as an IUD, the vast majority of women over the age of twenty-five instantly recognized it. Bursting into laughter, they'd often share an otherwise taboo fertility-related story about their mother, a friend, or themselves. Further, the sculpture required women to explain what the object was to their male-identifying or younger companions, placing their stories at the center of the project. This effect was exactly what I sought, I thought to myself. Soaring into the sky like a secular, feminist version of the Christ the Redeemer monument, ZAP! would boldly commemorate reproductive self-determination, science, and women's desire. 


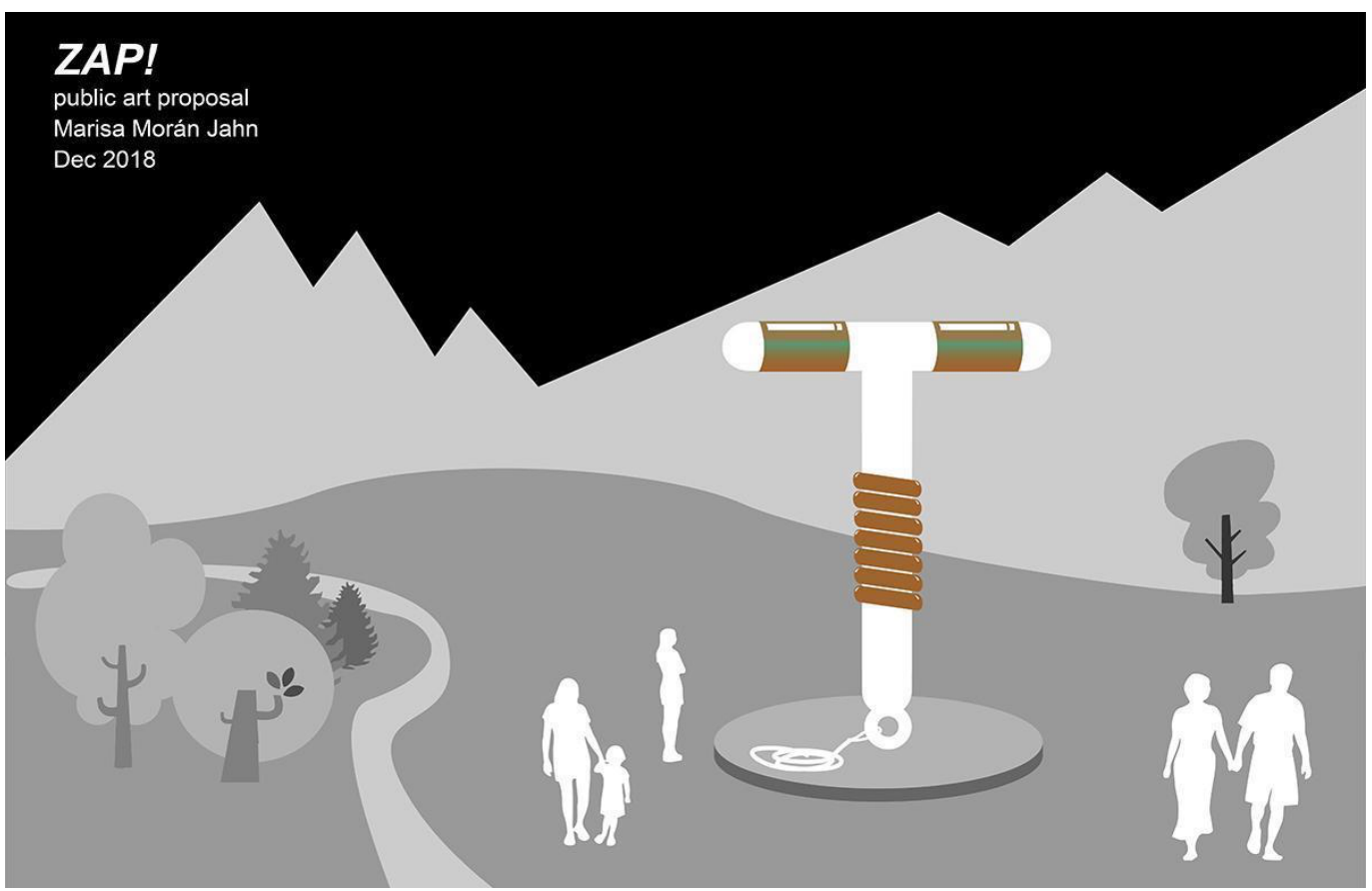

Figure 2. ZAP!, 2018, Marisa Morán Jahn, illustration @ Marisa Morán Jahn.

Created from bronze (an alloy created from copper and mineral additives), the sculpture, which I named, ZAP!, would be conductive. Worried it would attract lightning and electrocute its onlookers, I consulted lightning and grounding specialists. To my surprise, they were quite confident they could ground the sculpture, guaranteeing it would be safe for the public. As a lightning rod, ZAP! would function as a living "axis mundi," channeling electrons between the sky and earth-an interactive sculpture that invited us to see ourselves elementally.

I began looking for sites, learning about permitting processes, and drafting a fundraising plan. But a nagging feeling began to grow. To make this larger-than-life IUD, I would have to extract tons and tons of copper and other minerals-a process whose heavy ecological footprint would run counter to the project's very ethos. I wondered how else I could use my skills as an artist to invite people to feel this intersection between bodies and land.

Stage and lighting directions: Marisa is moping, perplexed about what to do. The lights dim. A video projected on the screen overhead or adjacent the podium attracts the audience's attention. Meanwhile, Marisa (who is out of the spotlight) changes into her costume and headdress to become Venus of Aphrodite. In her address to the audience, she starts off with some equanimity, then becomes indignant if not haughty. Marisa then temperamentally switches to a cloying and conciliatory tone and ends the performance as one would close a heated conversation with a lover. 


\section{ON EXTIMACY}

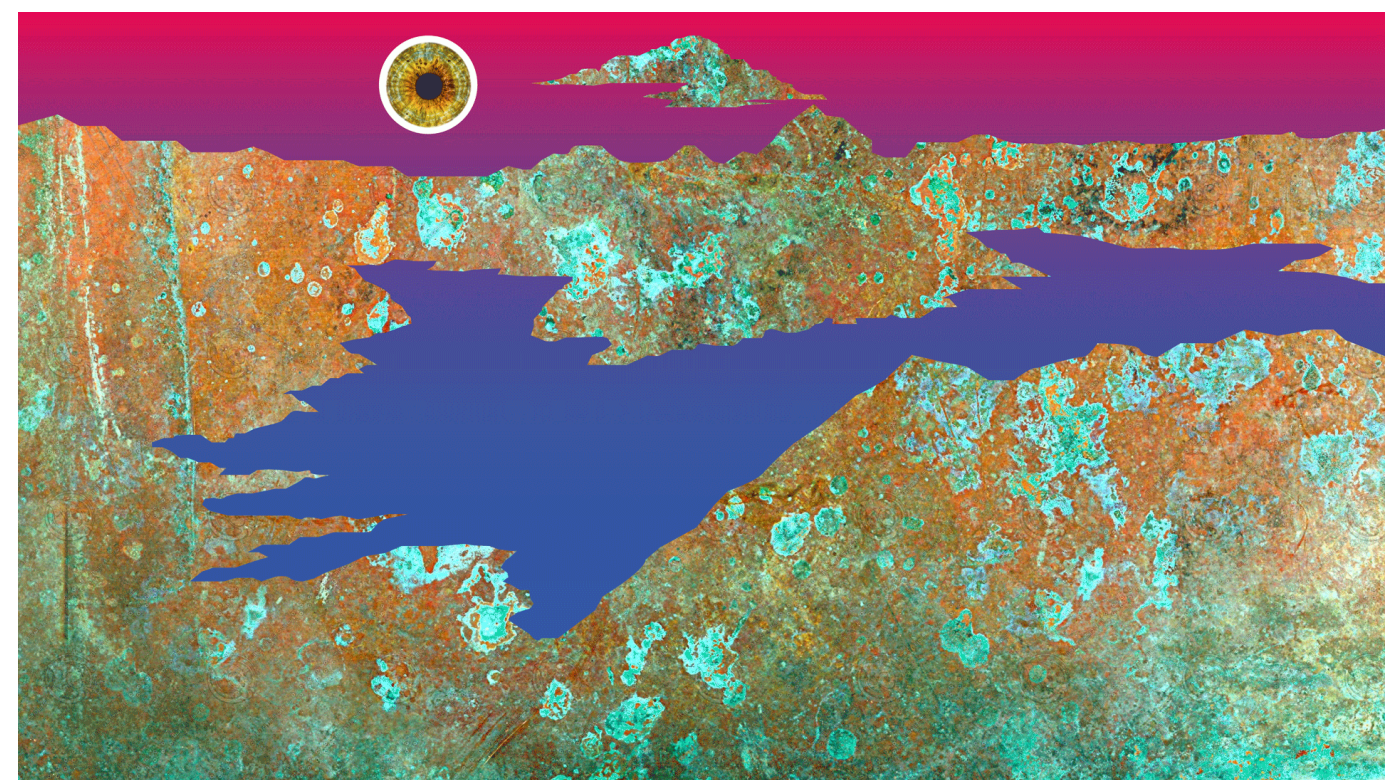

Figure 3. Copperscape 2, 2019, Marisa Morán Jahn, GIF @ Marisa Morán Jahn.

The yellowish eye is a telltale sign of Wilson's disease brought on by the overexposure of copper. Here, the artist draws on the iconography of the watchful eye, inviting us to witness the ecological destruction and public health impact of mining which adversely affects women of color in the Global South. 


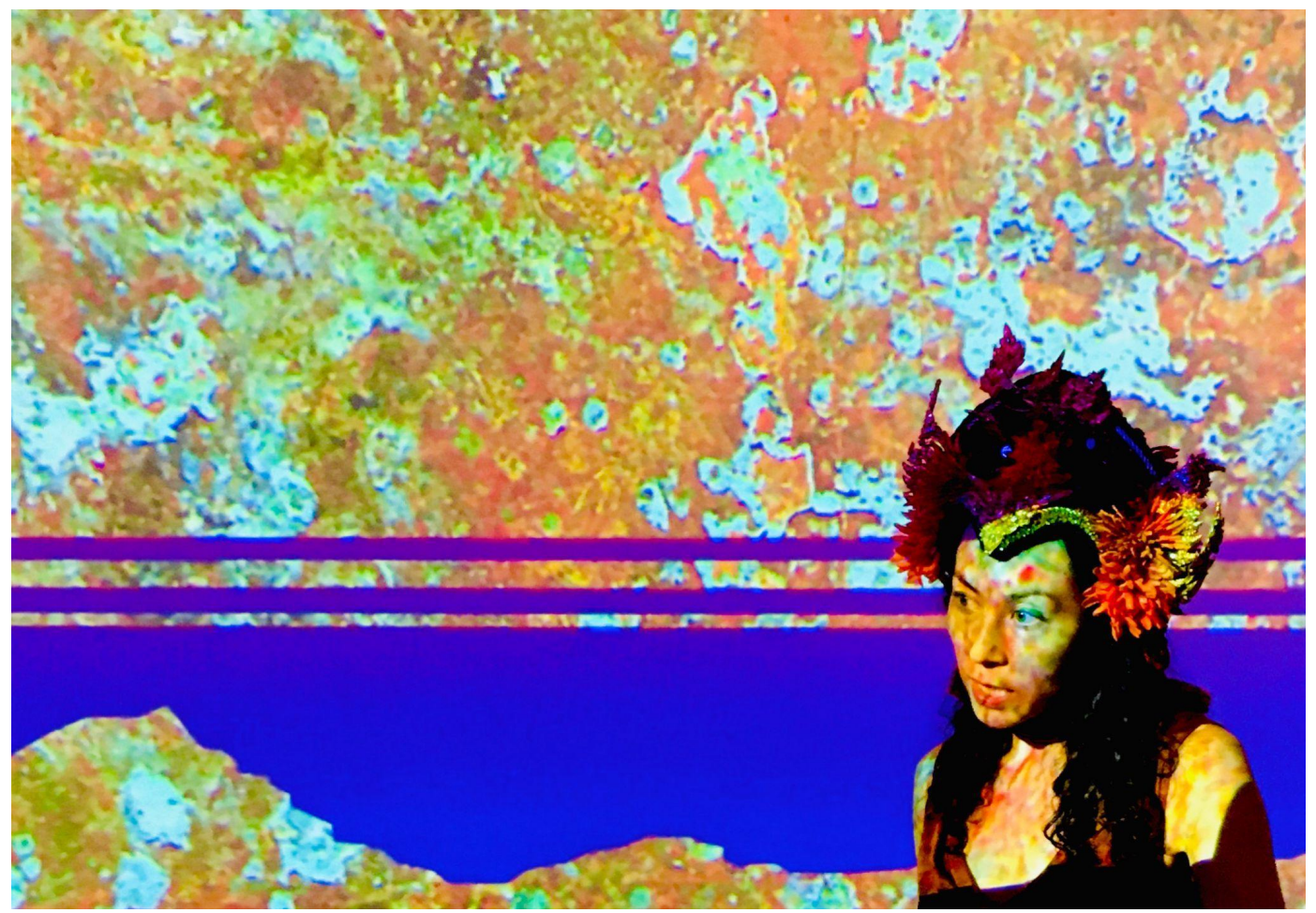

Figure 4. Marisa Morán Jahn as Aphrodite, 2020, photo by Paul Falzone @ Marisa Morán Jahn.

\section{MINES(S) and OTHERS}

I am Aphrodite.

Goddess of love and copper, which is why we share the same alchemical symbol, perhaps suggesting a relationship of fecundity.

In the West, people like to say I was first mined 10,000 years ago on the island of Cyprus where I existed in abundance.

But actually, I am everywhere around the world,

And I am up in you.

Your body needs and desires me.

But above 5 milligrams a day-I weaken you.

I already course through your veins.

For some of you dependent on love or pacemakers, I regulate your heart.

I might even be in your snatch, enabling libidinal pleasure through copper-based intrauterine devices.

Find me in motherboards, the central circuitry of a computer.

Tinder-pals and surrogate parents - I enable you to compute, manage, and facilitate desire and fertility. 
Since the advent of capitalism and the notion of the individuated self, you've thought of yourself as an interiorated, private, and self-contained body.

But you are a networked being in a digital era.

You depend on me to access your desire and digital selves,

whose ontic exhaust, to use Mark Jarzombek's term, I store and scatter throughout the world , spreading you wide and distending you — so while you thought you understood intimacy, you've misunderstood.

This is about extimacy - the technological mediation of intimacyintimacy mediated through an external element-mineral, copper, earth-ME.

But my love, what have you done to me? You've spent me, overused and abused me.

Devastated, I've spilled into $40 \%$ of America's waterways, poisoning your drink for hundreds of years to come.

For those who work in mines who handle and refine me, I'm afraid I've "overexposed" them. Over time, and through their labor, I will affect their breath, skin, and mental functioning until what seems most sovereign - their own body-

becomes OTHER.

And things are just getting worse: these days, I'm not just lying around on the crust of the earth and easy to mine.

You have been relying on my abundance for the past 10,000 years! Today I recede deep within the earth and to possess me you have to excavate volumes and volumes of ore to yield the same amount — which creates more tailings — which harms you.

I don't want us to be this way-I can't. We can't.

Because the dispossession of land and body both means your destruction.

Baby, we both know when this distance between me and you, mine(s) and others first began.

But now we need to stitch this distance.

In his writing on alchemy, the philosopher Giorgio Agamben reminds us, "The transformation of metals occurs hand in hand with the transformation of the subject... the care of the self necessarily passes through a work - it inextricably implies an alchemy."

And so, I ask you to feel me in you, transformed. 


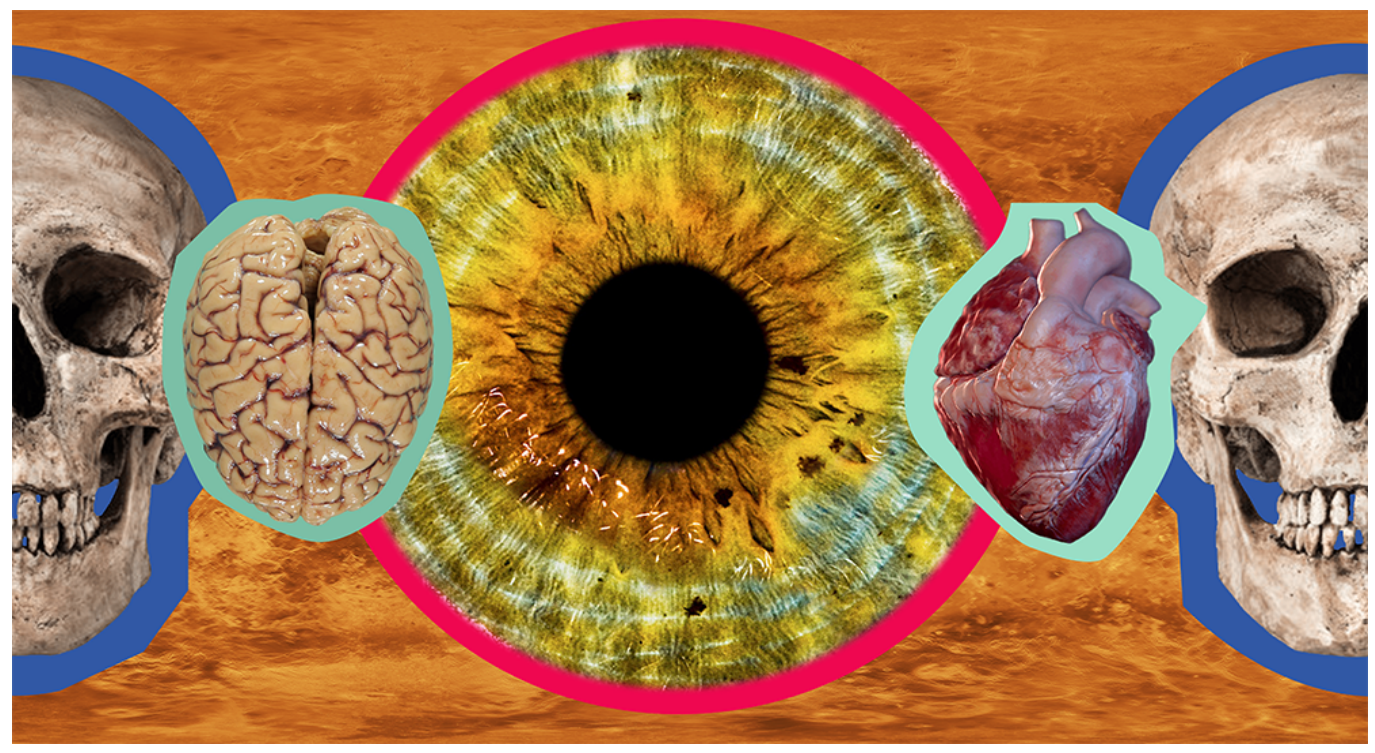

Figure 5. I Take Over Your Body, 2019, Marisa Morán Jahn, still from a GIF C Marisa Morán Jahn.

\section{ENDNOTES}

1. Bronze pessary, Science Museum Group, accessed September 11, 2020.

https:/collection.sciencemuseumgroup.org.uk/objects/co88665/bronze-pessary-roman-200-bce400-ce-pessary

2. "Contraceptive Use in 2019," United Nations Development Department of Economic and Social Affairs, 2020, accessed May 29, 2020.

https://www.un.org/development/desa/pd/sites/www.un.org.development.desa.pd/files/files/docu ments/2020/Jan/un_2019_contraceptiveusebymethod_databooklet.pdf

3. Chikako Takeshita, "Biopolitics of IUD: Strategies in the Global South," draft manuscript revised March 23, 2015; submitted to Travail, genera et société.

4. Cristina Cauterucci, "IUD Demand Has Risen 900 Percent Since the Election, Planned Parenthood Says," Slate (Jan. 10, 2017), accessed May 29, 2021. https://slate.com/humaninterest/2017/01/iud-demand-has-risen-900-percent-since-the-election-planned-parenthoodsays.html

5. Chikako Takeshita, The Global Biopolitics of the IUD: How Science Constructs Contraceptive Users and Women's Bodies (MIT Press, 2012).

6. Loretta J. Ross, Lynn Roberts, Erika Derkas, Whitney Peoples, and Pamela Bridgewater Toure, eds. Radical Reproductive Justice: Foundations, Theory, Practice, Critique (Feminist Press, 2017), p.25.

7. From conversations with Sherry Turkle, the author's former professor at MIT, 2006-2007. 8. Overburdened: Understanding the Impacts of Mineral Extraction on Women's Health in Mining Communities (Mining Watch, 2004). 
9. Kathryn Yusoff. A Billion Black Anthropocenes or None (Minneapolis University Press, 2018).

\section{REFERENCES}

Bauza, Vanessa. "Puerto Rico: The Covert Campaign to Sterilize Women." MS [new series] 5, no. 2 (September/October 1994): 14.

Boring, Catherine Chase. "Factors Associated with Sterilization Regret Among Puerto Rican Women.” Master's thesis, Emory University, 1986.

Bronze pessary, Science Museum Group, accessed September 11, 2020:

https://collection.sciencemuseumgroup.org.uk/objects/co88665/bronze-pessary-roman-200-bce400-ce-pessary

Falicov, T. La operación (1982), accessed October 30, 2017 :

http://www.filmandhistory.org/documentary/women/operacion.php

Kohls, Gary G. "Lessons from the Most Toxic Open Pit Copper Mine in the World," Duluth Reader (Dec 15, 2016), accessed September 1, 2020:

http://duluthreader.com/articles/2016/12/14/8500 lessons from the most toxic open pit coppe $\underline{\mathrm{r} \text { mine }}$

\section{AUTHOR BIO}

An artist/filmmaker of Ecuadorian and Chinese descent, Marisa Morán Jahn's creative media and public art "exemplifies the possibilities of art as social practice" (Artforum). Her work has been presented at the Museum of Modern Art, Tribeca Film Festival, United Nations, Obama's White House, and the Venice Biennale of Architecture. She is a Creative Capital and Sundance grantee and has taught at The New School, Columbia, and across departments at MIT (her alma mater). 